DOI: https://doi.org/10.32839/2304-5809/2019-6-70-56

UDC $101+159.99$

Malimon Vitalii

Ivano-Frankivsk National Technical University of Oil and Gas

\title{
SUICIDE AS AN OUTCOME OF PERSONS LONELINESS
}

Summary. The article investigates the relationship between the problem of loneliness and suicide. It is established that the cause of certain suicide types is the state of loneliness, alienation from social processes and the loss of the meaning of life. It is determined that the prevention of this phenomenon are the following solutions: escapism from the state of loneliness; acquisition of new identities; awareness of the value of one's own life. Suicide prevention should be diverse, with a special emphasis on mental health issues. Such efforts should be comprehensive, aimed at creating a sense of security, the formation of healthy life scenarios and the avoidance of destructive negative loneliness.

Key words: loneliness, suicide, causes of suicide, existential needs of human being, «illness of developed intelligence».

Малімон B.I.

Івано-Франківський національний технічний університет нафти і газу

\section{САМОГУБСТВО ЯК НАСЛІДОК САМОТНОСТІ ЛЮДИНИ}

Анотація. У статті досліджено взаємозв'язок проблеми самотності та самогубства. Обірунтовано, що саме самотність часто виступае причиною зародження думок про самогубство, здійснення суїцидальних спроб. Ідея самогубства циркулюе в суспільній свідомості і відтворюеться різними засобами культури. Ставлення до самогубства в суспільстві, як і на рівні індивідуальної свідомості, тісно пов'язане з етичним відношенням до життя і смерті. Встановлено, що проблема самогубства постає актуальною в будь-який час індивідуального та суспільного життя. У людському житті є ймовірність втрати його смислу, що може стати однією 3 причин самогубства. Визначено, що умовою профілактики явища $є$ вихід зі стану самотності, набуття нових ідентичностей та усвідомлення цінності власного життя. Профілактика самогубств має бути різноплановою, із особливим акцентом на проблеми психічного здоров'я. Розрізняють первинну, вторинну та третинну профрілактику самогубств. Такі зусилля повинні бути комплексними, спрямованими на створення відчуття захищеності та відходу від руйнівної негативної самотності, формування здорових сценаріїв життя.

Ключові слова: самотність, самогубство, причини самогубства, екзистенційні потреби людського буття, «хвороби розвинутого інтелекту».

Tormulation of the problem. Over the past 50 years, the number of suicides around the world has increased by $60 \%$. Every 40 seconds on our planet someone deprives oneself of life. In some countries, suicide is one of the three main causes of death among people of 15-44 years of age, and the second most significant cause of death among young people between the ages of 10 and 24 . These numbers do not include suicide attempts that occur 20 times more often than actual suicide [20]. According to official statistics of the World Health Organization, 1100000 people each year commit suicide [11]. Approximately 20 million people attempt to commit a suicide each year; and as much as they try to shorten their age, which entails psychological consequences for the executer itself and, at a minimum, for those in ones environment. In the future the increase of these indicators is projected.

According to the World Health Organization, in 2017, about 15 thousand suicides were committed in Ukraine. The average indicator for our country is 22 suicides per 100 thousand population. Ukraine is among the top ten countries with the highest suicide rate. These statistics do not include cases of unsuccessful suicide attempts, which, according to psychologists, make up 6-7 cases per 100000 people [14]. Suicide is the leader of deaths in the Ukrainian Army (more than 50\%). The reason is the difficult adaptation of the military to physical and psychological stress. Anxiety causes an increase in the number of suicides among teenagers (an increase of three times during the last decade).
Analysis of recent research and publications. The topic of suicide was repeatedly investigated in the writings of Aristotle, Socrates, Cicero, Marcus Aurelius, Descartes, Spinoza, J.-L. Montesquieu, J.-J. Russo, M. Berdyaev, F. Dostoevsky, E. Durkheim, S. Kierkegaard, F. Nietzsche, E. Fromm, Z. Freud et al. Suicide and ways of its prevention were also studied by Ukrainian scholars A. Bakcherikov, Y. Bashmanovska, V. Koshetar, E. Matuzok, V. Moskalets, O. Oliynyk, S. Pavlenko, T. Tkachenko and others, who expressed quite different opinions not only about the reasons for the existence of the phenomenon under consideration, the methods of its prevention, but also about the relationship of suicide with person loneliness.

Identification of previously unsettled parts of the general problem. The development of a modern post-industrial society is characterized by accelerated pace of change, the emergence of new factors and trends affecting the suicidal behavior of the inhabitants of different countries and, accordingly, require the improvement of existing measures of counteraction and development of new ones. This necessitates the study of suicide at this stage of development of society as a socio-philosophical phenomenon.

The aim of the article. The main purpose of this article is to reveal the essence of the phenomenon of suicide in the socio-philosophical context; detection of its conditionality as a factor of loneliness of a person.

Results of the research. Suicide is one of the eternal problems of mankind; it has been existing 
in humanity since they appeared on Earth. Suicide is the only human behavioral act of self-alienation from life. E. Durkheim, author of the first fundamental sociological work devoted to suicide (1897), defines a suicide as a conscious act of the victim, the consequences of which are predicted and expected fatal outcome of the specified individual [6, p. 26].

A. Camus, a representative of the philosophy of existentialism, believes that there is only one truly serious philosophical problem - the problem of suicide. To decide whether or not is the life worth living - is an answer the fundamental question of philosophy [7, p. 223].

S. Avanesov writes, that science cannot define what lays in the roots of suicide, therefore the philosophy is the carries of needed answers [1, p. 13]. It is the philosophy that can determine what a suicide is and, therefore, with which research program it should be approached. Philosophical suicidology, by virtue of its presence, confirms the inevitable limitations of private methods of science, and thus reveals the relativity of any scientific conclusion on suicide [1, p. 14-15].

Early descriptions of suicides are found in all the oldest manuscripts: Rigweed, Ramayana, Bible, Koran. They are given not only descriptions of cases, types, methods, suicides in different nations, but also reflect the motives that lead to the action. For example, Muslims are asked to pay attention to the real causes of the problem. Among them is the weakness of the faith (Iman) or its lack of communication with Allah (dua), lack of hope for Allah and despair, lack of patience, lack of knowledge about punishment for suicide, lack of true guidance in life, refusal to commemorate Allah (dhikr). The obstacle Islam puts in the path of suicide is faith in predestination (qadar). Believing that all the benefits of a Muslim are given to him by Allah to the needed extent. Knowing this, the faithful muslim understands that the life situation in which he is present is best for him at this time, because all the forbearance of Allah is the only true and have the exclusive benefit. Suicide can be a consequence of complex external circumstances, heredity, peculiarities of the nervous system [8].

E. Durkheim proposed his social theory of suicide, according to which suicide is the result of an individual's rupture of relationships with the social group to which one previously belonged. According to him, "the number of suicides in society is determined» by collective representations "as special factors of social life, which determine the individual vision of the world (values, moral norms)» [6, p. 17].

E. Durkheim distinguishes three main categories of suicides: 1) selfish suicide, the beginning of which - in alienation. People committing this type of suicide have little to do with the outside world, other people; they are prone to loneliness, constant analysis of the state of their consciousness. In this case, the "decoupling does not have anything passionate»: a person accurately determines the time and way of his death; the last moments of ones life are painted with calm melancholy; person does not stop self-examination until the very end. About egocentric suicide is also said when a person kills oneself, realizing the impossibility of subsequent careless and easy life, focused on providing sensual pleasures; kills himself with ironic indifference, calm and peculiar simplicity; 2) Altruistic suicide is carried out by people who are closely connected with other people, team and are ready to go for the sake of others for all (Kamikadze pilots of the Second World War, our contemporaries who were engaged in self-burning to attract attention to a certain problem). This type of suicide is often characterized by the clear uncertainty that generates a sense of fulfilled duty. Sometimes this act may have a more passionate and less conscious character - as a aspiration in faith and enthusiasm; 3) Anemic suicide is carried out in a fanatical annoyance, disappointment or anger, when the relationship between man and society suddenly and shockingly changes [10].

E. Durkheim conducts an analysis of statistic data that characterizes the dynamics of suicide in European countries. Suicide occurs more often among Protestants than Catholics; single people are more likely to commit suicide than married ones; in military service suicides are more frequent than among civilian population; in peacetime, the number of suicides is bigger than during wars and revolutions; during periods of economic increase and decrease suicidea occur more often than in stability periods; suicides happen more often in cities than in rural areas.

According to E. Durkheim, the state of loneliness precedes the suicide, along with the alienation of a person from social processes and, finally, the loss of the meaning of life. The reason for this is an egocentric lifestyle, concentration only on ones own needs and the inability to go beyond their own Self. Therefore, when an individual breaks his ties with the social environment, he immediately experiences loneliness, and subsequently loses his sense of life, which may lead to suicide. On this case, the researcher states: "...if <...> individualism leads a person to suicide, an underdeveloped individuality can also lead to the same results. When a person is separated from society, then it is easy for one to start thinking about eliminating oneself from life; the same thing happens to a person when society completely and completely absorbs ones individuality" [6, p. 196]. As we see, the first type of suicide is related to the loneliness of man, the inability to establish constructive social relations.

The prominent philosopher M. Berdyaev carried out a thorough philosophical study of the interrelationship problem between loneliness and suicide. He analyzes the problem of suicide in the context of the life of Russian emigrants. Investigating their fate, he explains the general psychological and philosophical origins of the suicide problem. According to M. Berdyaev, existential vacuum that arose in the psyche of people, has its origins from the October Revolution of 1917. The intelligentsia, feeling the lack of meaning of these events, perceived this as a collapse of their life expectations. He notes: "The loss of any meaning of life, separation from the Motherland, the unfulfilled expectations, loneliness, disease, a sharp change in social status ... all of this greatly contributes to the epidemic of suicide" $[4 ; 2$, p. 5]. The philosopher states that, although at first sight, suicide has an individual character, it goes beyond the limits of individual life in social space. Man by his actions indirectly affects the actions of others. In committing suicide, one shows an example of destructive behavior to others. M. Berdy- 
aev notes that "suicide is contagious and a person who kills himself, carries out a social act, pushes others towards the same way, creates a psychological atmosphere of degradation" [2, p. 5].

In public consciousness, it is sentenced to treat suicides with condemnation, however, M. Berdyaev appeals to philosophical comprehension of such a deed. He believes: when a person is torn from social environment, loses touch with historical roots, there is a state of loneliness, which determines the act of suicide. "It's very difficult for a person to stay isolated, lonely, detached from <...> native soil, feel abandoned $<\ldots>$ And if human life is not strengened with faith, $<\ldots>$ the burden becomes impossible» $[2$, p. 6$]$.

M. Berdyaev distinguishes a number of reasons for suicide: detached love, disappointment in family relationships, loss of curiosity to life, helplessness, loss of dignity, illness, etc. However, in his opinion, whatever the cause, the suicider, as a rule, is in a state of hopelessness. This feeling, regardless of what it is caused by, can cause a fatality in human life. Thus, M. Berdyaev writes: «Suicide by its nature is the denial of the three highest Christian values: faith, hope and love. Suicider is a person who lost faith. God, a good power that governs life, is no longer real to them» [2, p. 9].

The suicide act has an egocentric nature, a person does not think about the close ones. Consequently, the focus on their own negative experiences and alienation from the outside world are the causes of suicide. Instead, Berdyaev states that a man must overcome hate, reject negative egocentric thoughts and love oneself: «There are responsibilities not only to God and others, but to himself. It is necessary to be good to ourselves, not to behave badly, not to carry out self destruction, not to mistreat your own soul and body. Suicide is a very bad attitude towards oneself, a violation of the duty towards oneself» $[2$, p. $15 ; 4]$.

Consequently, the problem of suicide appears relevant at any time of both individual and social life. In human life there is a chance of losing its meaning, which can be one of the causes of suicide. According to M. Berdyaev, by exiting the state of existential crisis, a person attempts to flesh out all the events of personal and social life, along with sufferings. Man has to get out of a state of loneliness, to step on the path of transcendence, to expand ones own consciousness to the level of personal values [4].

Edwin Schneidman [19] in his suicide theory describes mental pain (emotional or psychological) as the main motivation for such an attempt. He claims that suicide occurs when the threshold of tolerance for psychological pain is exceeded and this threshold is different among different people. Internal motives for suicide, especially emotional pain and hopelessness, often serve as motives for suicide attempts.

According to E. Schneidman, the purpose of the suicide is to find a solution. "Suicide is not a casual act. It never ends up aimlessly. It is a way out of the situation, a way of solving a life problem, dilemma, duty, a state of difficulty, a crisis or an intolerable situation» [16, p. 293].

Having examined the perception of the tragically-hopeless position of man on earth as a factor in suicidal attitudes, V. James stated that based on the attitude towards the evil that exists in the world, people can be divided into «once born» - optimists and "twice-born» - pessimists. The psyche of pessimists is unbalanced, which, in particular, manifests itself as a total (all-embracing) disappointment and pessimism, generated by a radical contradiction between their real-self and ideal-self. Ideal-self strives for harmony with the world, formed by the high sense of life, the organic inclusion of man as an integral, necessary part in the beautiful perspective of his infinite perfection, fulfilling the joy of being, life's inspiration and inspiration, etc. However real-self does not find such meanings in real life, in which all lives are doomed to inevitable death. Awareness of this fact generates a condition that V. James called "a disease of developed intelligence». The main symptoms of this "disease» are disappointment in life's baits, anhedonia (nothing really pleases), boredom, aversion to the world and to oneself, which can lead to suicide. The only, truly effective, according to V. James, is "medicine» from «illness of developed intelligence» - the achievement of the "peak of consciousness", on which - the belief in the Supreme mind, God, which gave a high meaning to human existence, is concerned with the fate of mankind and each man gives everyone hope and a chance for a happy, full of truth, kindness and beauty of immortal life [5, p. 73-157; 9].

Outstanding philosophers, such as: M. Buber, E. Husserl, S. Kierkegaard, M. Scheler, L. Shestov, K. Jaspers, striken from «illness of developed intelligence» dicease, have created existentialism the philosophy of existence. There are many differences in their writings, but the "cry» of despair, which ended with the comprehension of the situation of man in the world to each of them, sounds the same.

Prospecting the meaning of the "cry» of despair, A. Camus pointed out that he was - from the painful contradiction between the desire of man to an infinite, eternal harmonious relationship with the world, comprehensive, cosmic significance, and awareness of his own meticulousness, finality, the inevitability of death, the fundamental indifference of the world to her personally and to each person. Man is in a state of multidimensional existential conflicts: between the pursuit of harmony, excellence, greatness and real experience of the imperfections of the world and of their own insignificance, of wickedness; between the desire to be caring and loving, kinship-accepted, harmoniously integrated, identified by society, and feeling of misunderstanding, rejection, alienation, radical loneliness; between the desire to live, to rejoice in life and the heavy burden of senselessness, absurdity, cruelty, injustice, and the exhausting of human life on land, hopeless separation of people from each other because of egoism [9].

German philosopher A. Schopenhauer considers the main underlying cause of suicide to be physiological disorders of self-slaughter's health. "If a complicated temper, a bad mood due to bodily abnormalities (which occur in most cases, in the nervous system) reach a very high degree, then the slightest trouble is a sufficient motive for suicide» [17, p. 355].

Investigating the relationship between the problem of loneliness and suicide, E. Fromm drews attention to the fact that a person dares to commit a suicide when there are no other means to overcome loneliness: "Suicide is the last hope, if all other attempts to remove the burden of loneliness were un- 
successful» [15, p. 133]. At the same time, E. Fromm is convinced that suicide is not a constructive method of overcoming loneliness, and therefore describes suicide as «the highest deviation of life» [15, p. 223].

B. Kennedy [13] mentions several risk criteria:

1. Lonely men (divorced and those with no close friends) over the age of 40 .

2. Individuals living alone.

3. Alcoholics.

4. People who have experienced a great loss.

5. Older people with somatic diseases.

Suicide prevention should be diverse, with a special emphasis on mental health issues. There are several preventions of suicides: primary, secondary and tertiary. Primary prevention aims to reduce the number of new suicides commited in certain population. Secondary prevention should reduce the likelihood of suicidal attempts by those who have already made an attempt to escape and are in at high risk. Tertiary prevention aims at reducing the number of suicide attempts that arise in response to a completed / unfinished suicide attempt that took place certain area [2].

Foreign researchers [18] offer 5 main areas of preventive work that can reduce the number of suicides:
1. Educational and scolastic programs for the general population and specialists of somatic practice.

2. Wide introduction of screening methods for the identification of people in high-risk groups.

3. Improvement of the results of treatment for people with mental disorders.

4. Restricted access to means of committing suicide.

5. Developing a policy on coverage of the problem in the media.

Conclusions and suggestions. Consequently, it can be argued that loneliness is often the cause of the suicide thoughts arousement along with further execution. The idea of suicide circulates in the public consciousness and is reproduced by various means of culture. The attitude to suicide at both social, and individual levels of consciousness, is closely linked to the ethical attitude to life and death.

Measures to prevent suicide require the coordination and co-operation of a wide range of sectors of society, including law, education, health sector, intra-family work and the media. Such efforts should be comprehensive and complex, aimed at creating a healthy picture of the world, delivering a sense of security and avoiding destructive negative loneliness.

\section{References:}

1. Avanesov S.S. (2000). Vvedenie v filosofskuyu suitsidologiyu [Introduction to the psychology of suicide]. Tomsk : Tomsk University publishing house, $122 \mathrm{p}$.

2. Berdiaev N. (1992). O samoubiystve [About suicide]. Moskow : Moskov University publishing house, $24 \mathrm{p}$.

3. Bacherikow A.M., Matuzok E.G., Lakinsky R.V., Tkachenko T.V. Suitsydalna povedinka ta yii profilaktyka (ohliad literatury). [Suicidal behavior and its prevention (literature overview)]. Retrieved from: http://nbuv.gov.ua/ UJRN/Uvp_2012_20_2_14

4. Bashmanivska Ya. (2014). Vzaiemozviazok problemy samotnosti ta samohubstva [Interrelation between suicide and loneliness]. Skhid (electronic journal), no. 1, pp. 175-179. Retrieved from: http://nbuv.gov.ua/UJRN/ Skhid_2014_1_33

5. James W. (1993). Mnogoobrazie religioznogo opyta [The Varieties of Religious Experience]. Saint Petersburg : Andreev i syinovya, $418 \mathrm{p}$.

6. Durkheim E. (1998). Samoubiystvo: Sotsiologicheskiy etyud [Suicide, etude de sociologie]. Saint Petersburg : Soyuz, $496 \mathrm{p}$.

7. Camus A. (1990). Buntuyuschiy chelovek. Filosofiya. Politika. Iskusstvo. [The Rebel. Philosophy. Politics. Art]. Moskov : Politizdat, $415 \mathrm{p}$.

8. Koshetar U.P. Suitsyd ta evtanaziia yak problemy suchasnoietyky [Suicide and uthanasia as problems of modern ethics]. Retrieved from: http://nbuv.gov.ua/UJRN/Vnau_f_2013_1_9

9. Moskalets V., Oliinyk A. Relihiina vira yak antysuitsydalnyi chynnyk [Religion as a prevention of suicide]. Retrieved from: http://ena.lp.edu.ua/bitstream/ntb/42317/2/2018v12_Moskalets_VRelihiina_vira_yak_ antysuitsydalnyi_58-75.pdf

10. Pavlenko S.V. Psykholohiia suitsydu [Psychology of suicide]. Retrieved from: http://molodyvcheny.in.ua/files/ journal/2018/5/6.pdf

11. World Health Organization. Riven samohubstv. Pokaznyky v krainakh [Suicide levels in different countries]. Retrieved from: http://apps.who.int/gho/data/view.main.MHSUICIDEv

12. Horstnaya P.P., Titarenko T.M. (ed.) (2001). Slovar-spravochnik [Dictionary reference]. Kiev : Ruta, 320 p.

13. Mohovik A.N. (ed.) (2001). Suitsidologiya: proshloe i nastoyaschee: problema samoubiystva v trudah filosofov, sotsiologov, psihoterapevtov i $\mathrm{v}$ hudozhestvennyih tekstah : hrestomatiya [Suicidology: past and present: the problem of suicide in the writings of philosophers, sociologists, psychotherapists and in artistic texts : textbook]. Moskov : Kogito-Tsentr, 569 p.

14. Utrov Ye. (2018). Ukraina stala rekordsmenom Evropyi po kolichestvu suitsidov [Ukraine became the European record holder in the number of suicides]. Daily online newspaper «Utro». Retrieved from: http://www.utro.ua/ru/ proisshestviya/ukraina_stala_rekordsmenom_evropy_po_kolichestvu_suitsidov_4a07d9281ba27

15. Gurevych P.S. (ed., translated) (1989). Fromm E. Begstvo ot svobody [Fromm E. Escape from Freedom]. Moskov : Progress, $272 \mathrm{p}$.

16. Shneidman E.S. (2001). Dusha samoubiytsy [The soul of a suicider]. Moskov, 315 p.

17. Shopenhauer A. (1992). Mir kak volya i predstavlenie [The World as Will and Representation]. Moskov : Moskovskiy klub, vol. 1, 395 p.

18. Mann J.J., Apter A., Bertolote J. Suicide prevention strategies: a systematic review. JAMA. 2005. Vol. 294. Pp. 2064-2074.

19. Shneidman E.S. Suicide as Psychache: A Clinical Approach to Self-Destructive Behavior. Northfield, NJ : Jason Aronson, 1993. 270 p.

20. Why more men kill themselves than women. URL: http://www.bbc.com/future/story/20190313-why-more-menkill-themselves-than-women 


\section{Список літератури:}

1. Аванесов С.С. Введение в философскую суицидологию. Томск : Изд-во Томского университета, 2000.122 с.

2. Бердяев Н. О самоубийстве. Москва : Изд-во Моск. ун-та, 1992. 24 с.

3. Бачериков А.М., Матузок Е.Г., Лакинський Р.В., Ткаченко Т.В. Суїцидальна поведінка та їі профілактика (огляд літератури). URL: http://nbuv.gov.ua/UJRN/Uvp_2012_20_2_14

4. Башманівська Я. Взаємозв'язок проблеми самотності та самогубства. Схід. 2014. № 1. С. $175-179$. URL: http://nbuv.gov.ua/UJRN/Skhid_2014_1_33

5. Джемс В. Многообразие религиозного опыта. Спб. : Андреев и сыновья, 1993. 418 с.

6. Дюркгейм Э. Самоубийство: Социологический этюд. Спб. : Союз, 1998. 496 с.

7. Камю А. Бунтующий человек. Философия. Политика. Искусство. Москва : Политиздат, 1990. 415 с.

8. Кошетар У.П. Суїцид та евтаназія як проблеми сучасної етики. URL: http://nbuv.gov.ua/UJRN/ Vnau_f_2013_1_9

9. Москалець В., Олійник А. Релігійна віра як антисуїцидальний чинник. URL: http://ena.lp.edu.ua/bitstream/ ntb/42317/2/2018v12_Moskalets_V-Relihiina_vira_yak_antysuitsydalnyi_58-75.pdf

10. Павленко С.В. Психологія суїциду. URL: http://molodyvcheny.in.ua/files/journal/2018/5/6.pdf

11. Рівень самогубств. Показники в країнах. Всесвітня організація охорони здоров'я. URL: http://apps.who.int/ gho/data/view.main.MHSUICIDEv

12. Словарь-справочник / под ред. П.П. Горностая и Т.М. Титаренко. Киев : Рута, 2001. 320 с.

13. Суицидология: прошлое и настоящее: проблема самоубийства в трудах философов, социологов, психотерапевтов и в художественных текстах : хрестоматія / под ред. А.Н. Моховикова. Москва : Когито-Центр, 2001. 569 с.

14. Утров Є. Украина стала рекордсменом Европы по количеству суицидов. Ежедневная Интернет-газета «Утро». 2018. URL: http://www.utro.ua/ru/proisshestviya/ukraina_stala_rekordsmenom_evropy_po_kolichestvu_ suitsidov_4a07d9281ba27

15. Фромм Э. Бегство от свободы; пер. с англ.; общ. ред. и послесл. П.С. Гуревича. Москва : Прогресс, 1989.272 с.

16. Шнейдман С. Эдвин. Душа самоубийцы / [пер. с англ]. Москва, 2001. 315 с.

17. Шопенгауэр А. Мир как воля и представление. Собр. соч. в 5-ти т. Москва : Московский клуб, 1992. Т. 1. 395 с.

18. Mann J.J., Apter A., Bertolote J. Suicide prevention strategies: a systematic review. JAMA. 2005. Vol. 294. P. 2064-2074.

19. Shneidman E.S. Suicide as Psychache: A Clinical Approach to Self-Destructive Behavior. Northfield, NJ : Jason Aronson, 1993. 270 p.

20. Why more men kill themselves than women. URL: http://www.bbc.com/future/story/20190313-why-more-menkill-themselves-than-women 